Western University

Scholarship@Western

Paediatrics Publications

Paediatrics Department

$8-2017$

\title{
Choosing Wisely Canada: The Canadian College of Medical Geneticists' (CCMG) List of Five Items Physicians and Patients Should Question
}

Elaine Goh

Trillium Health Partners

Andrea Guerin

Kingston General Hospital

Joanna Lazier

University of Alberta

Sharan Goobie

IWK Health Centre

Tanya N. Nelson

University of British Columbia

See next page for additional authors

Follow this and additional works at: https://ir.lib.uwo.ca/paedpub

Part of the Pediatrics Commons

Citation of this paper:

Goh, Elaine; Guerin, Andrea; Lazier, Joanna; Goobie, Sharan; Nelson, Tanya N.; Agatep, Ron; Siu, Victoria Mok; Niederhoffer, Yaren Y.; and Richer, Julie, "Choosing Wisely Canada: The Canadian College of Medical Geneticists' (CCMG) List of Five Items Physicians and Patients Should Question" (2017). Paediatrics Publications. 126.

https://ir.lib.uwo.ca/paedpub/126 
Authors

Elaine Goh, Andrea Guerin, Joanna Lazier, Sharan Goobie, Tanya N. Nelson, Ron Agatep, Victoria Mok Siu, Yaren Y. Niederhoffer, and Julie Richer 


\title{
Choosing Wisely Canada: The Canadian College of Medical Geneticists' (CCMG) list of five items physicians and patients should question
}

\author{
Elaine Goh, ${ }^{1}$ Andrea Guerin, ${ }^{2}$ Joanna Lazier, ${ }^{3}$ \\ Sharan Goobie, ${ }^{4}$ Tanya N Nelson, ${ }^{5,6}$ Ron Agatep, ${ }^{7}$ Victoria Mok Siu, ${ }^{8}$ \\ Karen Y Niederhoffer, ${ }^{3}$ Julie Richer ${ }^{9}$
}

Choosing Wisely Canada aims to reduce patient harm by promoting discussion and awareness of unnecessary tests, procedures and treatments. Organised by Canadian physicians and the Canadian Medical Association, ${ }^{1}$ it is modelled after the American Choosing Wisely campaign. ${ }^{2}$ The concept of 'Choosing Wisely' is now an international effort, across more than 15 countries. $^{1}$

The advances in genome sequencing technology have allowed for increased diagnostic yield while unmasking secondary findings or information of limited clinical utility. ${ }^{3}$ These findings may contribute to further unnecessary diagnostic testing, lifelong surveillance for low-risk sequelae and side effects of preventative treatment in healthy individuals, all of which may have economic consequences. ${ }^{3}$ Therefore, recommendations by genetics professionals to improve health and decrease costs are needed.

The Canadian College of Medical Geneticists (CCMG) is the national organisation that establishes Canadian professional and ethical standards for medical genetics services. The CCMG through the leadership of the Ethics, Education, and

Department of Laboratory Medicine and Genetics, Trillium Health Partners, Mississauga, Canada ${ }^{2}$ Department of Pediatrics, Division of Medical Genetics, Kingston General Hospital, Kingston, Canada ${ }^{3}$ Department of Medical Genetics, University of Alberta, Edmonton, Canada

${ }^{4}$ Medical Genetics, Department of Pediatrics, IWK Health Centre, Halifax, Canada

${ }^{5}$ Department of Pathology and Laboratory Medicine, University of British Columbia, Vancouver, Canada ${ }^{6}$ Department of Pathology and Laboratory Medicine, BC Children's and BC Women's Hospitals, Vancouver, Canada

${ }^{7}$ Genomics, Diagnostic Services Manitoba, Winnipeg, Canada

${ }^{8}$ Division of Medical Genetics, Department of Pediatrics, London Health Sciences Centre, Western University, London, Canada

${ }^{9}$ Department of Medical Genetics, Children's Hospital of Eastern Ontario Research Institute, Ottawa, Canada

Correspondence to Dr Elaine Goh, Laboratory Medicine and Genetics, Trillium Health Partners, Mississauga, ON L5M 2N1, Canada; elaine.goh@thp.ca
Public Policy Committee (E2P2), undertook an iterative process to formulate five items physicians and patients should question in medical genetics as part of Choosing Wisely Canada.

The initial statements (Summer 2015) were generated by a subcommittee of E2P2. Seven statements with the option for additions were presented in a pilot survey at the 2015 CCMG annual conference. For reference, the five statements from the American Choosing Wisely campaign were also provided. ${ }^{4}$ After feedback, the statements from the pilot survey were modified or replaced by new ones and distributed to the entire CCMG membership $(n=318)$ by electronic survey (SurveyMonkey, San Mateo, California, USA) in March 2016 for ranking. Answers were weighted, and the five top statements were selected. The results of statement ranking by $53 / 318(17 \%)$ members responding to the electronic survey can be found in table 1 . The top five statements chosen for literature review are bolded.

E2P2 reviewed the literature, generated a rationale for each statement and presented these orally during the 2016 CCMG annual meeting for comment. Following revision, statements and their rationale were posted for comment online for 1 month with one reminder email sent to the membership. E2P2 reviewed comments and edited statements prior to submission to the 151 Choosing Wisely Society Leads from other specialties (Fall 2016). Comments were received and addressed, including a change from 'non-invasive prenatal testing' (NIPT) to 'non-invasive prenatal detection of fetal aneuploidies by cell-free DNA' and keeping the term 'children' rather than 'minors' despite objection, to be consistent with other society statements. ${ }^{56}$

The final statements as below were submitted to the Choosing Wisely Canada organisation on 1 January 2017:
DON'T USE NON-INVASIVE PRENATAL DETECTION OF FETAL ANEUPLOIDIES BY CELL-FREE DNA AS A DIAGNOSTIC TEST

Non-invasive prenatal detection of fetal aneuploidies by cell-free DNA, also called non-invasive prenatal testing and non-invasive prenatal screening, is a method of non-invasive fetal DNA testing done through a maternal blood sample. NIPT testing for common aneuploidies, microdeletions and sex chromosome disorders ${ }^{7}$ is clinically available to patients in Canada. NIPT is a highly sensitive and specific screening test but is not diagnostic. ${ }^{8}$ Even in high-risk populations, there can be false-positive NIPT results. Genetic counselling, along with confirmatory testing via amniocentesis or chorionic villus sampling, should be done prior to using the result to impact management of a pregnancy.

\section{DON'T MAKE MEDICAL DECISIONS}

BASED ON RESULTS OF DIRECT TO CONSUMER GENETIC TESTING WITHOUT A CLEAR UNDERSTANDING OF THE LIMITATIONS AND VALIDITY OF THE TEST Three types of potentially medically relevant direct to consumer genetic testing (DTC-GT) are available: (1) assessment of risk for common multifactorial diseases (eg, diabetes); (2) targeted mutation analysis for single gene disorders; and (3) sequencing. Some DTC-GT companies state that they do not guarantee the accuracy or reliability of their tests. Many of the significant genetic risk and protective factors for multifactorial conditions have not been identified. This leads to greatly divergent risk interpretations between companies, even when performed on the same individual. ${ }^{9}$ For targeted mutation analysis and sequencing, the specific test may not include all clinically relevant genes or mutations, resulting in false reassurance. ${ }^{10}$ Genetic changes that are only weakly associated with disease may be reported, leading to anxiety or inappropriate additional testing. When making medical decisions based on results of genetic testing, the test should meet the recommendations made by the CCMG in 2012. ${ }^{11}$ Not all DTC-GT meet these recommendations.

\section{DON'T ORDER A CHROMOSOME ANALYSIS BY DOING A KARYOTYPE FOR INDIVIDUALS WITH INTELLECTUAL DISABILITY/DEVELOPMENTAL DELAY OF UNKNOWN AETIOLOGY}

Microarray is the first-line test for individuals with intellectual disability/ 
Table 1 Rating average following the membership survey $(n=53)$

\begin{tabular}{lll}
\hline Statements & Response count & Rating average* \\
\hline Don't order whole exome sequencing prior to genetic counselling. & 42 & 3.60 \\
\hline $\begin{array}{l}\text { Don't make medical decisions based on results of direct to consumer genetic testing (DTC-GT) without having a clear } \\
\text { understanding of the limitation and validity of the specific test used. }\end{array}$ & 39 & 3.54 \\
\hline $\begin{array}{l}\text { Don't order carrier testing in paediatric patients if these results will not impact their health care management in the } \\
\text { paediatric period. }\end{array}$ & 41 & 26 \\
\hline $\begin{array}{l}\text { Don't use NIPT as a diagnostic test. } \\
\text { Don't do a karyotype in a patient presenting for developmental delay (as microarray is now the standard of care). }\end{array}$ & 41 \\
\hline $\begin{array}{l}\text { Don't order an amniocentesis for an increased maternal AFP if the 18-20 week ultrasound was normal with adequate visualisation. } \\
\text { Don't do a karyotype if a microarray has already been ordered/performed. }\end{array}$ & 22 & 3.49 \\
\hline Don't order genetic testing for HFE-related hemochromatosis in patients who have an isolated mild elevation of ferritin. & 28 & 2.79 \\
\hline
\end{tabular}

*Weighted based on whether statement was chosen as first, second, third, fourth or fifth choice.

AFP, alpha feto protein; NIPT, non-invasive prenatal testing.

Bolded statements selected for literature review.

developmental delay without a recognisable syndrome. ${ }^{12}$ Indeed, a microarray has a much higher detection rate $(15 \%-20 \%)$ compared with a karyotype $(3 \%-4 \%)$ in individuals presenting for this clinical indication. ${ }^{13} \mathrm{~A}$ karyotype remains important in limited clinical situations where a specific numerical or structural chromosomal syndrome, such as Down syndrome, is suspected.

\section{DON'T ORDER WHOLE EXOME SEQUENCING (WES) PRIOR TO GENETIC COUNSELLING}

WES is a powerful test for individuals suspected of having an underlying genetic diagnosis. However, WES increases the likelihood of unexpected findings, which may or may not be clinically significant. Furthermore, due to methodological limitations, WES may not always be the correct test to order as WES will not detect all genetic causes of disease (eg, it will not detect chromosomal structural differences). ${ }^{14}$ Both informative and uninformative results can lead to complex patient and family psychosocial repercussions ${ }^{15}$ and could impair future insurability. Genetic counselling facilitates informed decision making. Given complexity of results, WES should only be ordered after counselling by a qualified healthcare provider.

\section{DON'T ORDER CARRIER TESTING IN CHILDREN}

Carrier testing is primarily useful in the reproductive period to determine the risk of an individual having a child affected by the condition for which testing is being considered. ${ }^{5}$ Knowing that a child is a carrier of an X-linked or autosomal recessive condition usually does not alter medical care in the paediatric years since most carriers are unaffected. Thus, in most situations, there is not a medical indication for carrier testing in a child. ${ }^{6}$ Undertaking carrier testing of a child violates the right of the child to make his or her own decision about testing and could impair future insurability. An exception could be made for a mature adolescent who may be able to understand the reproductive implications of carrier testing after appropriate genetic counselling.

This expert CCMG consensus reflects Choosing Wisely statements covering a broad range of genetic issues relevant to Canadians. As no demographic information was collected from the membership survey, it is not known whether the responses were representative of both laboratory geneticists and clinical geneticists, but there were equal opportunities for both to provide feedback.

It is interesting that only one statement regarding WES is similar to the American recommendations. ${ }^{4}$ While the American version was specific about recommending informed consent, particularly around secondary findings, the Canadian version recommends genetic counselling, which is more generalised and would encompass informed consent as part of the counselling process. Three of the American statements target specific genetic tests (APO-E, MTHFR and HFE). ${ }^{4}$ In Canada, some of these tests are not routinely offered or covered by provincial healthcare. It is possible that the perspective taken in generating these recommendations in the USA versus Canada differs based on the target audience requesting the tests, the healthcare systems or the practice differences between the two countries. Regardless of the reason, this report suggests that there is value in determining country-specific recommendations. As technology and knowledge advance, these statements may need to be revised.
As the goal of the Choosing Wisely campaign is to reduce patient harm by generating greater awareness of responsible use of testing and procedures, these five recommendations represent the start of a dialogue that will hopefully optimise utilisation of resources related to medical genetics.

Acknowledgements The authors would like to thank the members of E2P2, the CCMG and the Choosing Wisely Canada Society Leads for their participation and feedback. The authors would also like to thank Professor Timothy Caulfield for his input regarding one of the statements.

Contributors ES-YG wrote the first draft of the manuscript, coordinated the revisions and submitted the manuscript. JR led the campaign, created, analysed and administered the surveys, presented the statements at the annual meetings and collected feedback. ES-YG, $A G, J L, K Y N$ and JR each wrote a statement rationale. ES-YG, AG, SG, TNN, RA, VMS, KYN and JR helped in the brainstorming discussions that led to the statement formulation as well in refining statement rationale. All authors commented on various versions of the manuscript, agreed on the final version to be published and can attest to the integrity of the work.

Competing interests None declared.

Provenance and peer review Not commissioned; internally peer reviewed.

(C) Article author(s) (or their employer(s) unless otherwise stated in the text of the article) 2018. All rights reserved. No commercial use is permitted unless otherwise expressly granted.

\section{Check for updates}

To cite Goh E, Guerin A, Lazier J, et al. J Med Genet 2018;55:86-88.

Received 14 July 2017

Accepted 18 July 2017

Published Online First 19 August 2017

J Med Genet 2018;55:86-88.

doi:10.1136/jmedgenet-2017-104924

\section{REFERENCES}

1 Canada CW. What is choosing wisely Canada? secondary what is choosing wisely Canada? 2017 http://choosingwiselycanada.org/. 
2 American Board of Internal Medicine. Choosing Wisely. Secondary Choosing Wisely. http://www. choosingwisely.org/.

3 Burke W, Trinidad SB, Clayton EW. Seeking genomic knowledge: the case for clinical restraint. Hastings Law J 2013:64:1650-64.

4 American Board of Internal Medicine. ACMG Provides Recommendations on Genetic Testing Through the Choosing Wisely Campaign. Bethesda, MD: Choosing Wisely; 2015.

5 Arbour L, Society CP. Guidelines for genetic testing of healthy children. Paediatr Child Health 2003;8:42-5.

6 Committee on Bioethics, Committe on Genetics, American College of Medical Genetics, Genomics Social, Ethical, Legal Issues committee. Ethical and policy issues in genetic testing and screening of children. Pediatrics 2013;131:620-2.

7 Benn P, Chapman AR. Ethical and practical challenges in providing noninvasive prenatal testing for chromosome abnormalities: an update. Curr Opin Obstet Gynecol 2016;28:1-24.

8 Mersy E, Smits LJ, van Winden LA, de Die-Smulders CE, Paulussen AD, Macville MV, Coumans AB, Frints SG;
South-East Netherlands NIPT Consortium. Noninvasive detection of fetal trisomy 21: systematic review and report of quality and outcomes of diagnostic accuracy studies performed between 1997 and 2012. Hum Reprod Update 2013;19:318-29.

9 Peikoff K. I had my DNA Picture taken, with varying results. The New York Times. 2013 (December 30, 2013).

10 Caulfield T, Borry P. Direct-to-consumer genetic testing - where should we focus the policy debate? Med J Aust 2013;198:499-500.

11 Nelson TN, Armstrong L, Richer J, Evans J, Lauzon J, McGillivray B, Bruyere H, Dougan S; CCMG Ethics and Public Policy Committee. CCMG statement on directto-consumer genetic testing. Clin Genet 2012;81:1-3.

12 Moeschler JB, Shevell M; Committee on Genetics. Comprehensive evaluation of the child with intellectual disability or global developmental delays. Pediatrics 2014;134:e903-18

13 Michelson DJ, Shevell MI, Sherr EH, Moeschler JB, Gropman AL, Ashwal S. Evidence report: genetic and metabolic testing on children with global developmental delay: report of the Quality Standards
Subcommittee of the American Academy of Neurology and the Practice Committee of the Child Neurology Society. Neurology 2011;77:1629-35

14 Sawyer SL, Hartley T, Dyment DA, Beaulieu CL, Schwartzentruber J, Smith A, Bedford HM, Bernard G, Bernier FP, Brais B, Bulman DE, Warman Chardon J, Chitayat D, Deladoëy J, Fernandez BA, Frosk P, Geraghty MT, Gerull B, Gibson W, Gow RM, Graham GE, Green JS, Heon E, Horvath G, Innes AM, Jabado N, Kim RH, Koenekoop RK, Khan A, Lehmann OJ, Mendoza-Londono R, Michaud JL, Nikkel SM, Penney LS, Polychronakos C, Richer J, Rouleau GA, Samuels ME, Siu VM, Suchowersky O, Tarnopolsky MA, Yoon G, Zahir FR, Majewski J, Boycott KM; FORGE Canada Consortium, Care4Rare Canada Consortium. Utility of whole-exome sequencing for those near the end of the diagnostic odyssey: time to address gaps in care. Clin Genet 2016;89:275-84.

15 Krabbenborg L, Vissers LE, Schieving J, Kleefstra T, Kamsteeg EJ, Veltman JA, Willemsen MA, Van der Burg S. Understanding the psychosocial effects of WES test results on parents of children with rare diseases. $J$ Genet Couns 2016:25:1207-14. 